\title{
PEMANFAATAN FITOPLANKTON UNTUK MENEKAN PERKEMBANGAN BAKTERI BERCAHAYA (Vibrio harveyi)
}

\author{
Imam Taufik", Zafran", Isti Koesharyani"), dan Des Roza Boer")
}

\begin{abstract}
ABSTRAK
Penyakit yang disebabkan oleh Vibrio harveyi merupakan kendala bagi usaha perbenihan udang windu (Penaeus monodon). Upaya pemberantasan dengan menggunakan antibiotik telah banyak dilakukan tetapi hasil yang dicapai belum memuaskan. Sehubungan dengan hal tersebut perlu dicari metode penanggulangan yang lebih efektif dan aman, di antaranya secara biologis dengan menggunakan fitoplankton.

Tiga jenis fitoplankton: Chaetoceros ceratosporum, Tetraselmis tetrathele dan Thalassiosira spp. diuji daya hambatnya terhadap perkembangan $V$. harveyi dalam pemeliharaan larva udang windu pada kondisi laboratorium. Kultur murni $V$. harveyi diinfeksikan ke dalam air pemeliharan larva sebanyak $8,9 \times 10^{4} \mathrm{cfu} / \mathrm{ml}$ dengan kepadatan fitoplankton yang diberikan $20.000 \mathrm{sel} / \mathrm{ml}$. Ternyata dalam waktu 24 jam $C$. ceratosporum sanggup menurunkan kepadatan $V$. harveyi dalam air pemeliharaan larva dari jumlah yang diinfeksikan menjadi $8,0 \times 10^{2} \mathrm{cfu} / \mathrm{ml}, T$. tetrathele $9,0 \times 10^{3}$ $\mathrm{cfu} / \mathrm{ml}$, Thalassiosira spp. $4,3 \times 10^{4} \mathrm{cfu} / \mathrm{ml}$ dan pada kontrol kepadatan $V$. Harveyi mencapai $6,0 \times 10^{8}$ cfu/ml.

Sintasan larva udang windu $C$. ceratosporum memberikan hasil yang lebih baik $(49,61 \%)$ dibanding $T$. tetrathele $(27,92 \%)$, Thalassiosira spp. (17,65\%) maupun kontrol $(5,24 \%)$. Selain itu, C. ceratosporum juga merupakan pakan alami yang baik bagi larva udang windu.

ABSTRACT : Inhibition of luminescent Bacteria (Vibrio harveyi) by phytoplankton.
By: Imam Taufik, Zafran, Isti Koesharyani and Des Roza Boer.

Luminescent Vibrio harveyi disease, is a serious threat in hatchery of Penaeus monodon, and may cause mass mortality in a short time. Antibiotics are used widely to treat the bacterial disease but not always succesfull due to limited knowledge on the effects of these drugs. Phytoplankton believed to be effective to control bacteria in the rearing water of prawns or shrimps. Three kinds of phytoplankton, namely Chaetoceros ceratosporum, Tetraselmis tetrathele and Thalassiosira spp. were tested to inhibit the growth of luminescent $V$. harveyi on the culture of $P$. monodon in laboratory condition. The experiment was arranged in Completely Randomized Design with 3 replications. The results showed that $C$. ceratosporum may decrease the density of $V$. harveyi from $8.9 \times 10^{4} \mathrm{cfu} / \mathrm{ml}$ to $8.0 \times 10^{2} \mathrm{cfu} / \mathrm{ml}, T$. tetrathele from $8.9 \times 10^{4} \mathrm{cfu} / \mathrm{ml}$ to $9.0 \times 10^{3}$ $\mathrm{cfu} / \mathrm{ml}$, and Thalassiosira spp. from $8.9 \times 10^{4} \mathrm{cfu} / \mathrm{ml}$ to $4.3 \times 10^{4} \mathrm{cfu} / \mathrm{ml}$. On the other hand the control (without phytoplankton) showed that density of $V$. harveyi increase up to $6.0 \times 10^{5} \mathrm{cfu} / \mathrm{ml}$ after 24 hours infection. Survival rate of $P$. monodon larvae after 24 hours infection in each treatment were $49.61 \%$ for C. ceratosporum, $27.92 \%$ for T. tetrathele, $17.65 \%$ for Thalassiosira spp., and $5.24 \%$ for control. As conclusion, $C$. ceratosporum was found to be most effective to inhibit the growth of $V$. harveyi and provided the highest survival rate of $P$. monodon larvae.
\end{abstract}

KEYWORDS: Vibrio harveyi, phytoplankton, bacteria inhibitor.

\section{PENDAHULUAN}

Lesunya usaha perbenihan udang windu (Penaeus monodon) yang dialami dewasa ini terutama disebabkan oleh tingginya mortalitas larva yang antara lain akibat infeksi bakteri bercahaya dari jenis vibrio (Anonymous, 1991; Rukyani et al., 1992). Karena itu para pengelola panti benih banyak yang beralih ke jenis komo. ditas lain seperti udang putih yang dianggap lebih tahan terhadap penyakit, meskipun nilai ekonomisnya tidak setinggi udang windu.

Peneliti pada Loka Penelitian Perikanan Pantai Gondol, Bali. 
Pengelola panti benih pada umumnya menggunakan antibiotik untuk menanggulangi bakteri bercahaya ( $V$. harveyi) tetapi dalam penggunaannnya seringkali tidak terkontrol sehingga hasil yang diperoleh tidak efektif (Zafran dan Roza, 1993). Tindakan demikian dapat meningkatkan resistensi bakteri terhadap antibiotik (Rukyani et al., 1992) serta mencemari lingkungan perairan yang pada gilirannya akan dapat menimbulkan masalah baru bagi usaha perbenihan.

$V$. harveyi akan bersifat patogen bagi larva udang windu bila kepadatannya dalam air pemeliharaan larva telah mencapai $8,35 \times 10^{4} \mathrm{cfu} / \mathrm{ml}$ atau lebih sehingga dalam upaya penanggulangannya tidak perlu dibasmi sampai habis, hanya perlu dikendalikan populasinya pada batas yang aman, yaitu $<10^{4} \mathrm{cfu} / \mathrm{ml}$ (Zafran dan Roza, 1993). Dengan demikian diperlukan metode pemantauan secara rutin setiap hari terhadap perkembangan $V$. harveyi pada masing-masing bak pemeliharaan larva.

Alternatif lain yang dapat dilakukan untuk mengendalikan $V$. harveyi dengan aman dan ramah lingkungan adalah secara biologis. Organisme yang mungkin dapat digunakan untuk tujuan tersebut antara lain fitoplankton karena fitoplankton bersifat antagonistik dengan Vibrio spp. (Kogura et al., 1980). Sehubungan dengan hal tersebut, penelitian bertujuan untuk mengetahui jenis fitoplankton yang mempunyai kemampuan dalam menghambat $V$. harveyi sekaligus dapat dijadikan pakan alami bagi larva udang windu. Diharapkan dari hasil penelitian ini ditemukan metode penanggulangan $V$. harveyi secara efektif dan aman.

\section{BAHAN DAN METODE}

Penelitian dilakukan di laboratorium penyakit Loka Penelitian Perikanan Pantai Gondol. Wadah penelitian berupa botol kaca volume 3 liter, diisi air laut yang telah disterilkan menggunakan autoclave (suhu $121^{\circ} \mathrm{C}$ selama 15 menit) dengan volume masing-masing wadah 1 liter. Hewan uji adalah larva udang windu (zoea-1) yang diperoleh dari panti benih komersil. Sebelum ditebar larva direndam dalam larutan Oxytetracyclin (OTC) pada konsentrasi $10 \mathrm{ppm}$ selama 60 menit, kemudian dibilas dengan air laut steril dan ditebar dengan kepadatan 100 ekor/l.
Setiap wadah penelitian dilengkapi aerasi dan ditempatkan dalam bak berisi air (waterbath) untuk mencegah goncangan suhu. Larva diinfeksi dengan cara menambahkan suspensi isolat aktif $V$. harveyi hasil kultur murni pada media Marine Agar (MA), ke dalam air pemeliharaan larva hingga kepadatan masing-masing $8,9 \times 10^{4} \mathrm{cfu} / \mathrm{ml}$. Perlakuan berupa pemberian pakan alami (fitoplankton) dari jenis yang berbeda (A: Chaetoceros ceratosporum; B: Tetraselmis tetrathele; C: Thalassiosira spp.). Fitoplankton yang digunakan merupakan hasil kultur murni di laboratorium yang bebas bakteri vibrio (tidak tumbuh bakteri pada media selektif TCBSA) dan diberikan dengan kepadatan $20.000 \mathrm{sel} / \mathrm{ml}$ untuk setiap perlakuan. Sebagai kontrol adalah larva yang hanya diinfeksi $V$. harveyi tanpa fitoplankton.

Rancangan yang digunakan acak lengkap dengan tiga ulangan. Perhitungan sintasan larva (SR) dan kepadatan bakteri $V$. harveyi dalam air pemeliharaan dilakukan setelah 24 jam perlakuan. Data sintasan ditransformasikan ke dalam arcsin untuk selanjutnya dilakukan sidik ragam pada selang kepercayaan $95 \%$ serta uji Beda Nyata Terkecil (BNT) untuk melihat pengaruh perlakuan.

\section{HASIL DAN PEMBAHASAN}

\section{Perkembangan Bakteri Bercahaya}

Dalam waktu delapan jam setelah infeksi ternyata $V$. harveyi mulai menunjukkan patogenisitasnya terhadap larva udang windu, ditandai dengan bercahayanya larva dalam kondisi gelap yang menandakan bahwa telah terjadi akumulasi bakteri $V$. harveyi dalam tubuh larva terutama pada hepatopankreas. Pada kontrol (tanpa fitoplankton) secara jelas terlihat bahwa jumlah larva yang terinfeksi $V$. harveyi (larva bercahaya) jauh lebih banyak dibanding dengan larva yang diberi fitoplankton.

Hasil perhitungan kepadatan bakteri dalam air pemeliharaan larva setelah 24 jam infeksi menunjukkan bahwa jumlah $V$. harveyi paling tinggi ditemukan pada kontrol bahkan meningkat dari jumlah yang diinfeksikan yaitu dari $8,9 \times 10^{4}$ $\mathrm{cfu} / \mathrm{ml}$ menjadi $6,0 \times 10^{5} \mathrm{cfu} / \mathrm{ml}$. Ini menandakan bahwa $V$. harveyi mampu berkembang karena menemukan media yang layak serta tidak ada 
Table 1. Density of $\boldsymbol{V}$. harveyi and survival rate of $\boldsymbol{P}$. monodon larvae for each treatment after 24 hours infection.

\begin{tabular}{cccc}
\hline Treatment & $\begin{array}{c}\text { Initial density of } \\
\text { V.harveyi (cfu/ml) }\end{array}$ & $\begin{array}{c}\text { Density of V. harveyi } \\
\text { after 24 hours (cfu/ml) }\end{array}$ & $\begin{array}{c}\text { Survival rate of } \boldsymbol{P} . \\
\text { monodon larvae (\%) }\end{array}$ \\
\hline$A$ & $8.9 \times 10^{4}$ & $8.0 \times 10^{2}$ & $58.67^{a} \pm 2.646$ \\
$B$ & $8.9 \times 10^{4}$ & $9.0 \times 10^{3}$ & $23.33^{b} \pm 17.388$ \\
$C$ & $8.9 \times 10^{4}$ & $4.3 \times 10^{4}$ & $10.00^{b c} \pm 7.810$ \\
Control & $8.9 \times 10^{4}$ & $6.0 \times 10^{5}$ & $1.33^{c} \pm 1.527$ \\
\hline
\end{tabular}

Note: $\mathrm{A}=$ C. ceratosporum; $\mathrm{B}=T$. tetrathele; $\quad \mathrm{C}=$ Thalassiosira spp.

Values in column followed by same letters are not significantly different $(P>0.05)$

faktor pembatas/penghambat bagi perkembangannya. Hal sebaliknya terjadi pada air pemeliharaan larva yang diberi perlakuan penambahan fitoplankton (A, B, dan C) di mana jumlah $V$. harveyi cenderung menurun (Table 1).

Menurunnya kepadatan $V$. harveyi pada perlakuan $\mathrm{A}, \mathrm{B}$ dan $\mathrm{C}$ dari jumlah yang diinfeksikan berkaitan erat dengan keberadaan fitoplankton yang diberikan sebagai perlakuan karena sel-sel fitoplankton bersifat antagonistik dengan Vibrio spp. (Kogura et al., 1980) di mana fitoplankton mempunyai aktivitas sebagai antibakteri (Lewis et al., dalam Lavilla-Pittogo et al., 1992), dengan demikian akan menjadi kompetitor bagi $V$. harveyi sehingga perkembangannya terhambat.

Terdapat hubungan terbalik (korelasi negatif) antara fitoplankton dan bakteri, di mana klorofila dari fitoplankton meningkat pada siang hari dan menurun pada malam hari tetapi sebaliknya jumlah bakteri akan menurun pada siang hari dan meningkat pada malam hari (Kadowaki dan Tanaka, 1994). Hal tersebut tidak terlepas dari proses fotosintesa sel fitoplankton yang menghasilkan suatu bahan organik yaitu berupa karbohidrat atau polisakarida seperti yang dikemukakan oleh Austin et al. (1992). Dari kedua hasil penelitian tersebut dapat diasumsikan bahwa karbohidrat polisakarida mempunyai peran yang penting dalam menekan perkembangan bakteri.

\section{Sintasan Larva Udang Windu}

Keberadaan fitoplankton dalam mendukung sintasan larva udang windu selama penelitian terutama disebabkan oleh kemampuan fitoplankton dalam menghambat perkembangan $V$. harveyi dibanding sebagai pakan alami sebab larva udang windu pada stadia zoea awal (zoea-1) walaupun telah mulai melakukan aktivitas makan dengan cara menyaring air, akan tetapi laju konsumsi pakannya masih rendah. Terlihat dari hasil perhitungan fitoplankton yang diberikan di mana jumlahnya tetap untuk setiap perlakuan $(20.000 \mathrm{sel} / \mathrm{ml})$ setelah $24 \mathrm{jam}$.

Patogenisitas $V$. harveyi terhadap larva udang windu sangat dipengaruhi oleh kepadatannya dalam air pemeliharaan larva, semakin tinggi kepadatan $V$. harveyi akan bertambah patogen terhadap larva dan sebaliknya. Dari perhitungan sintasan larva udang windu pada akhir penelitian ternyata hasil paling tinggi dicapai pada perlakuan A (C. ceratosporum) yang mengalami penurunan kepadatan $V$. harveyi paling besar disusul oleh perlakuan B (T. tetrathele) dan C (Thalassiosira spp.). Sintasan terburuk diperoleh pada kontrol di mana kepadatan $V$. harveyi mengalami peningkatan. Persentase sintasan larva secara lengkap dapat dilihat pada Table 1.

Sidik ragam menunjukkan perbedaan yang nyata $(\mathrm{P}<0,05)$ antara perlakuan $\mathrm{A}(C$. ceratosporum) dengan perlakuan B (T. tetrathele), C (Thalassiosira spp.) dan kontrol. Perlakuan B tidak berbeda $(\mathrm{P}>0,05)$ dengan perlakuan $C$ tetapi berbeda nyata dengan kontrol $(\mathrm{P}<0,05)$, sedangkan antara perlakuan $\mathrm{C}$ dengan kontrol tidak berbeda nyata $(P>0,05)$. Ini berarti bahwa pemberian fitoplankton dari jenis $C$. ceratosporum merupakan yang terbaik dalam mendukung sintasan larva udang windu yang terinfeksi 
bakteri $V$. harveyi dibanding dengan pemberian T. tetrathele maupun Thalassiosira spp., terlebih lagi dibandingkan dengan tanpa pemberian fitoplankton. Hal tersebut diduga karena aktivitas dari sel-sel $C$. ceratosporum sebagai antibakteri lebih tinggi sebab C. ceratosporum mampu memproduksi substansi polisakarida lebih banyak dibanding $T$. tetrathele maupun Thalassiosira spp. di mana substansi polisakarida yang diproduksi tersebut merupakan zat yang dapat menghambat perkembangan $V$. harveyi dan menurunkan patogenisitasnya terhadap larva udang windu. Ini terbukti dari hasil perhitungan jumlah bakteri di mana pada perlakuan pemberian $C$. ceratosporum jumlah $V$. harveyi dalam air pemeliharaan larva paling rendah $\left(8,0 \times 10^{2} \mathrm{cfu} / \mathrm{ml}\right)$ dan jumlah tersebut berada di bawah kepadatan $V$. harveyi yang membahayakan bagi larva udang windu, yaitu $8,35 \times 10^{4} \mathrm{cfu} / \mathrm{ml}$ (Zafran dan Roza, 1993).

Pada perlakuan penambahan $T$. tetrathele maupun Thalassiosira spp. meskipun jumlah $V$. harveyi dalam air pemeliharaan larva pada akhir penelitian berkurang dan berada pada batas yang aman, yaitu $<8,35 \times 10^{4} \mathrm{cfu} / \mathrm{ml}$, tetapi laju penurunan $V$. harveyi lebih lambat dibanding dengan perlakuan penambahan C. ceratosporum sehingga terjadi periode yang lebih panjang pada awal penelitian di mana $V$. harveyi yang diinfeksikan ke dalam air pemeliharaan dengan kepadatan $8,9 \times 10^{4} \mathrm{cfu} / \mathrm{ml}$ dapat menginfeksi larva udang windu dan menyebabkan kematian bagi larva. Pada kontrol jumlah $V$. harveyi dalam air pemeliharaan pada akhir penelitian bertambah dari jumlah yang diinfeksikan, karena itu terinfeksinya larva oleh $V$. harveyi tidak terhindarkan sehingga menghasilkan sintasan paling rendah yaitu $5,24 \%$.

Beberapa penelitian telah membuktikan bahwa Tetraselmis suecica mempunyai kemampuan dalam menghambat vibrio yang patogen bagi udang (Austin dan Day, 1990) dan bakteri yang patogen terhadap ikan karena $T$. suecica mampu menghasilkan senyawa antibakteri yang telah berhasil diekstrak dan dikelompokkan sebagai polisakarida (Austin et al., 1992). Terbukti pula bahwa Tetraselmis suecica selain mampu menurunkan jumlah bakteri dalam tangki pemeliharaan juga mampu menurunkan mortalitas terhadap bakteri patogen (Austin et al., 1992).

\section{Fitoplankton sebagai Pakan Alami}

Tujuan utama pemberian fitoplankton adalah sebagai pakan alami bagi larva. Pakan alami seperti fitoplankton, zooplankton dan bentos berperan sebagai sumber karbohidrat, lemak dan protein dengan susunan asam amino yang lengkap bagi larva atau benih ikan, udang dan hewan akuatik lainnya. Di samping mengandung gizi yang lengkap dan mudah dicerna, pakan alami juga tidak mencemari lingkungan perairan dan media pemeliharaan larva (Ismi et al., 1991).

Beberapa pakan alami yang dapat digunakan untuk larva udang antara lain Chaetoceros ceratosporum, Tetraselmis spp., Skeletonema spp. ataupun dari jenis Isochrysis (Quinitio dan Villegas, 1982). Tetapi menurut Javellana (1990) Tetraselmis spp. tidak memadai dalam meningkatkan laju pertumbuhan dari stadia mysis hingga post larva walaupun ada laju cerna maksimum pada larva, sehingga pakan alami ini dianggap kurang baik untuk stadia tersebut.

Pernyataan di atas membuktikan bahwa $C$. ceratosporum merupakan jenis fitoplankton yang cukup baik untuk diberikan sebagai pakan alami bagi larva udang windu di samping keunggulan lain dalam menekan perkembangan $V$. harveyi.

\section{KESIMPULAN}

Chaetoceros ceratosporum mempunyai daya hambat lebih besar terhadap perkembangan $V$. harveyi dibanding Tetraselmis tetrathele maupun Thalassiosira spp. sehingga memberikan sintasan yang lebih baik bagi larva udang windu yang terinfeksi $V$. harveyi. Selain itu, C. ceratosporum merupakan pakan alami yang cukup baik bagi larva udang windu ( $P$. monodon).

\section{DAFTAR PUSTAKA}

Anonymous. 1991. Kasus serangan penyakit kunangkunang (Luminescent vibrosis) pada hatchery udang windu di daerah Jawa Timur. Laporan Bulanan Pusat Penelitian dan Pengembangan Perikanan Jakarta.

Austin, B., and J.G. Day. 1990. Inhibition of prawn pathogenic Vibrio spp by a commercial spray dried preparation of Tetraselmis suecica. Aquaculture, 90: 389-392. 
Austin, B., E. Baudet, and M. Stobie. 1992. Inhibition of bacterial fish pathogens by Tetraselmis suecica. Journal of Fish Diseases, 15(1): 55-61.

Ismi, S., Haryanti., A. Kholik, dan H. Eda. 1991. Perkembangan stadia, pertumbuhan dan kelangsungan hidup udang windu, Penaeus monodon dengan pemberian pakan alami yang berbeda. Jurnal Penelitian Budidaya Pantai, 7(1): 51-56.

Javellana, G.L.N. 1990. Behavioral and growth responses of prawn larvae to food density. SEAFDEC Asian Aquaculture, 1(12): 1.2

Kadowaki, S., Y. Tanaka. 1994. Interrelationship between phytoplankton and bacteria in culture pond of Kuruma prawn, Penaeus japonicus. Suisanzoshoku Kagoshima University Japan.

Kogura, K., U. Simidu, and N. Tuga. 1980. Effect of phyto and zooplankton on the growth of marine bacteria in filtered seawater. Bulletin of the Japanese Society of Scientific Fisheries 46(3): 323326.
Lavilla-Pitogo, C.R., L.J Albright, M.C. Paner and N.A Sunaz. 1992. Study on the sources of luminescent bacteria, Vibrio harveyi in Penaeus monodon hatcheries. p. 157-164. In M. Shariff, R.P Subasinghe and J.R Arthur (eds.). Disease in Asia Aquaculture I. Fish Health Section, Asia Fisheries Society, Manila, Philippines.

Quinitio, E.T., and C.T. Villegas. 1982. Growth, survival, and macronutrient composition of Penaeus monodon Fab. larvae fed with Chaetoceros calcitran and Tetraselmis chuii. Aquaculture, 29: 253-260.

Rukyani, A., P. Taufik dan Tauchid. 1992. Penyakit kunang-kunang (Luminescent vibriosis) dan cara penanggulangannya di hatchery udang windu. $\mathrm{pp}$. 47-60 Dalam Prosiding Seminar Sehari Upaya Penanggulangan Penyakit Benur pada Hatchery Udang, Surabaya, 20 Februari 1992.

Zafran dan D. Roza. 1993. Teknik penanggulangan penyakit udang menyala di hatchery melalui pengendalian populasi bakteri. Jurnal Penelitian Budidaya Pantai, 9(2): 127-132. 